Article

\title{
Impacts of Cd on Temporal Dynamics of Nutrient Distribution Pattern of Bletilla striata, a Traditional Chinese Medicine Plant
}

\author{
Jiyuan Yang ${ }^{1} \oplus$, Hui Sun ${ }^{1} \oplus$, Jihong Qin ${ }^{2, *}$, Xiaoqin Wang ${ }^{1}$ and Wenqing Chen ${ }^{1}$ \\ 1 Department of Environmental Science and Engineering, School of Architecture and Environment, \\ Sichuan University, Chengdu 610065, China; yangjiyuan@stu.scu.edu.cn (J.Y.); sunhui@scu.edu.cn (H.S.); \\ wangxiaoqinscu@sina.com (X.W.); chenwenqing@scu.edu.cn (W.C.) \\ 2 Department of Environmental Engineering, School of Architecture and Civil Engineering, \\ Chengdu University, Chengdu 610106, China \\ * Correspondence: qinjihong@cdu.edu.cn; Tel.: +86-158-8219-8525
}

Citation: Yang, J.; Sun, H.; Qin, J.; Wang, $X_{\text {.; }}$ Chen, W. Impacts of $\mathrm{Cd}$ on Temporal Dynamics of Nutrient

Distribution Pattern of Bletilla striata, a Traditional Chinese Medicine Plant. Agriculture 2021, 11, 594.

https://doi.org/10.3390/

agriculture11070594

Academic Editor: Yinbo Gan

Received: 8 May 2021

Accepted: 22 June 2021

Published: 26 June 2021

Publisher's Note: MDPI stays neutral with regard to jurisdictional claims in published maps and institutional affiliations.

Copyright: (c) 2021 by the authors. Licensee MDPI, Basel, Switzerland. This article is an open access article distributed under the terms and conditions of the Creative Commons Attribution (CC BY) license (https:// creativecommons.org/licenses/by/ $4.0 /)$.

\begin{abstract}
Bletilla striata is an endangered medicinal plant the habitats of which are polluted by cadmium (Cd). Nutrient management is a potential way to mitigate $\mathrm{Cd}$ toxicity, providing reference for B. striata artificial cultivation. Pot experiments were undertaken to examine the effect of five levels of Cd concentration (control: 0.28 mg $/ \mathrm{kg}$; I: $0.37 \mathrm{mg} / \mathrm{kg}$; II: $1.00 \mathrm{mg} / \mathrm{kg}$; III: $7.39 \mathrm{mg} / \mathrm{kg}$; IV: $54.6 \mathrm{mg} / \mathrm{kg}$ ) on the temporal dynamics of nutrient allocation in B. striata components. The results showed that the content and accumulation of $\mathrm{Cd}$ increased significantly in all tissues of Bletilla striata as $\mathrm{Cd}$ concentration was increasing, and most accumulated in the roots and slightly transferred to the aboveground parts, while tubers were less likely to accumulate $\mathrm{Cd}$. Excessive cadmium accumulation under long-term exposure reduced the biomass of all tissues of B. striata, and the yield was not significantly affected when cultivated in soil with a concentration of $\mathrm{Cd} \leq 1 \mathrm{mg} / \mathrm{kg}$. Potassium $(\mathrm{K})$ was quickly transferred from the root to other tissues in response to the $\mathrm{Cd}$ stress. The absorption of zinc ( $\mathrm{Zn})$ increased at first and then decreased with increased Cd concentration. According to Pearson correlation analysis, a mechanism is suggested that $\mathrm{Cd}$ accumulation affects the absorption of nutrients but is positively and significantly correlated with translocation factor of $\mathrm{K}$ and $\mathrm{Zn}$ in the tuber. This may imply that $B$. striata tends to promote the absorption of nutrient elements to adapt to the $\mathrm{Cd}$ enrichment in tubers and to compensate for the interrupted mineral nutrition metabolism.
\end{abstract}

Keywords: heavy metals; cadmium; phytotoxicity; nutritional allocation; traditional chinese medicine; Bletilla striata

\section{Introduction}

Bletilla striata (Thunb.) Rchb. f. (Orchid family) originated in China and is distributed in the middle and lower reaches of the Yangtze River and the southern region. The pseudobulbs of B. striata are widely known as Bletillae Rhizome and have been applied as hemostatic drugs for thousands of years [1]. Traditional Chinese Medicine (TCM) holds that Bletillae Rhizome is capable of stopping bleeding, promoting tissue regeneration and dispersing swelling. In recent years, Bletillae Rhizome has been paid more and more attention and prices have rocketed in China due to the increasing demand for medicinal products and falling rate of production, with 300 to $600 \mathrm{RMB}$ per $\mathrm{kg}$ in 2020. However, B. striata has become endangered due to limit of natural reproduction, increase in utilization and habitat destruction [2]. More than a decade ago, B. striata was listed as key protected wild medicinal plant (http:/ / rep.iplant.cn/, accessed on 5 February 2021), and was included in Appendix II of the Convention on International Trade in endangered species (CITES), requiring international protection. Currently, the China Food and Drug Administration (CFDA) has approved four patent drugs including Bai Ji Pill, Bai Ji Capsule, Bai Ji Syrup, and Bai Ji Granule, all of which only contain B. striata as the medicinal ingredient (http: / /www.sda.gov.cn/WS01/CL0001/, accessed on 8 February 2021). In order to solve the 
problem of limited wild resources of $B$. striata, artificial cultivation has been vigorously developed in southern China [3]. Among the many factors that affect the quality of B. striata, environmental pollution is the first, especially in developing countries, and cadmium $(\mathrm{Cd})$ pollution in soil has caused serious agricultural losses, and may cause health hazards through the food chain, affecting the medicinal value of traditional Chinese medicine $[4,5]$. Although there has been a large output of studies of $\mathrm{Cd}$ toxicity on crops over the last two decades, the impact on B. striata has not been considered, especially in the relation between nutrition allocation and $\mathrm{Cd}$ enrichment.

$\mathrm{Cd}$ is a hazardous heavy metal affecting plants when a certain concentration threshold is exceeded. Cd mainly accumulates in the roots of plants [6,7], which interferes with the growth and nutrient acquisition through the regulation of the rhizosphere environment [8]. When the $\mathrm{Cd}$ accumulates to toxic levels, severe physiological and biochemical disorders will be induced such as disturbances of nutrient absorption and transport which ultimately leads to production reduction [9]. Deficiency of any nutrient can cause obvious symptoms (such as chlorosis) and may be harmful to plants [10]. Potassium (K) is an effective activator of a variety of enzymes in plants and can also promote photosynthesis by increasing grana in the chloroplasts [11]. Calcium (Ca) is a necessary element for the maintenance of the membrane structure and cell wall [12]. Besides supporting plant growth, $\mathrm{Ca}^{2+}$ is also a cofactor for many biological enzymes involved in physiological metabolism. Magnesium $(\mathrm{Mg})$ is essential for the synthesis of chlorophylla and $\mathrm{CO}_{2}$ assimilation as the central atom in chlorophyll molecules [13]. Meanwhile, it is required for activating 1,5-biphosphate carboxylase. Zinc $(\mathrm{Zn})$ is an essential trace element in plants, which is also involved in the formation of chlorophyll and various enzymes and affects the synthesis of auxin [14]. The low level of the above nutrient elements may cause physiological disorders and stagnated growth in plants.

$\mathrm{Cd}$ has been proven by numerous studies to influence the uptake, translocation and metabolism of nutrients in crops such as rice, lettuce and welsh onions [15-19]. Cd is competitive with other cations having divalent properties for transporting proteins for metal ions entering and leaving the cells, so the uptake of $\mathrm{Cd}$ will affect the uptake and transport of nutrient elements [20]. Cd may also influence the permeability of cell membranes and change the protein conformation, thus changing the activity of the transporters, which may also interfere with the absorption and transportation of mineral nutrients. According to previous reports, the effect of $\mathrm{Cd}$ on nutrient uptake, translocation and metabolism depends on the plant species and genotypes, $\mathrm{Cd}$ accumulation, plant culture conditions, tested organs and development stage. Cd, to the plant in the content of $\mathrm{K}, \mathrm{Zn}, \mathrm{Mg}$ and $\mathrm{Ca}$, has both positive and negative effects because $\mathrm{Cd}$ directly affects the nutrient absorption and accumulation, whereas some nutrients can also protect the plant from the deleterious effects of $\mathrm{Cd}$ stress. The response is believed to be a plant regulatory mechanism in order to adapt to $\mathrm{Cd}$ stress by redistribution of the nutrients according to the different requirements of the plant components [16]. As reported by Kurtyka et al. [21], Cd stress caused K uptake reduction [22] which in turn may cause biosynthesis of carotenoid and chlorophyll to fail. It has been reported that due to the bivalent properties of $\mathrm{Cd}^{2+}, \mathrm{Cd}^{2+}$ is in fierce competition with $\mathrm{Ca}^{2+}$ and $\mathrm{Mg}^{2+}$ for transport on plasma films. There are also reports that $\mathrm{Cd}$ accumulation is positively correlated with the nutrient content due to increased uptake and/or translocation as a result of physiological changes in plants such as soil acidification caused by $\mathrm{Cd}$ which improves the biological availability of cations and the absorption of $\mathrm{Zn}^{2+}$.

Results of these reports are frequently contradictory. Although extensive research on $\mathrm{Cd}$ toxicity in plants has appeared in recent years, the importance of nutrition allocation (as a mechanism of protection to mitigate cadmium toxicity) is rarely studied [23] and it is problematic for accurate assessment of the risks of Cd contamination [24].

This is particularly true in that medicinal plants are affected by economic impact of $\mathrm{Cd}$ pollution, an issue that has been seriously underestimated and ignored. In addition, many studies on the effects of $\mathrm{Cd}$ on nutrient content and allocation are used in atypical growth conditions such as hydroponics and for short experiment periods. These conditions strongly 
affect the $\mathrm{Cd}$ in the influence of mineral nutrient absorption and transport [25]. Therefore, a pot experiment was used to study the effects of $\mathrm{Cd}$ pollution on $\mathrm{Cd}$ content, growth and the distribution pattern of the nutrient element in B. striata. the relationship between nutrient allocation and $\mathrm{Cd}$ enrichment in tubers, aiming to verify that the distribution of nutrients in different organs could affect the $\mathrm{Cd}$ accumulation of $B$. striata, and explore the relationship between nutrient allocation and $\mathrm{Cd}$ enrichment in tubers, the medicinal parts of $B$. striata. The ultimate aim was to provide the theoretical basis for further understanding the adaptation process and the $\mathrm{Cd}$ enrichment mechanism and information on the safe production of B. striata.

\section{Materials and Methods}

\subsection{Experimental Design}

The pot experiment was established in an experimental large canopy at Sichuan University in Chengdu, Sichuan Province, China: (104 $09^{\prime}$ E, $\left.30^{\circ} 64^{\prime} \mathrm{N}\right)$. We planted $50 B$. striata seedlings per pot and the culture medium was alluvial paddy soil from the Chengdu Plain. Three pots were set in each cadmium treatment group, and B. striata was randomly collected from three pots, respectively, as three replicates for each treatment. The total nitrogen content of the alluvial paddy soil was $1.803 \mathrm{mg} / \mathrm{kg}$, the total available phosphorus content $17.280 \mathrm{mg} / \mathrm{kg}$ and the total Cd content $0.285 \mathrm{mg} / \mathrm{kg}$. After the soil samples were collected, dried naturally, screened in a 100 mesh sieve, and mixed evenly with $5 \%$ humus soil and compound fertilizer, they were put into pots. There were five treatment groups and $\mathrm{Cd}$ was added in the form of $\mathrm{Cd}\left(\mathrm{NO}_{3}\right)_{2}$. Equal volumes of distilled water were added to the controls, and the soil in the pots was then mixed repeatedly to ensure homogenous distribution of the $\mathrm{Cd}$. For each treatment, the pots with soil were left for 2 weeks before transplantation to allow the $\mathrm{Cd}$ and the solid phase of the soil to reach equilibrium. At the end of this period, the soil samples were taken for analysis. The five $\mathrm{Cd}$ concentrations were $0.28 \mathrm{mg} / \mathrm{kg}$ (control), $0.37 \mathrm{mg} / \mathrm{kg}$ (I), $1.00 \mathrm{mg} / \mathrm{kg}$ (II), $7.39 \mathrm{mg} / \mathrm{kg}$ (III), $54.60 \mathrm{mg} / \mathrm{kg}$ (IV). Then, half of these pots for each treatment were transplanted with Bletilla striata (Thunb.) Rchb. f. seedlings in October 2018 and remained until May 2019, and all samples were examined in July, August and September, 2019 to determine the time dynamics of the nutrient pattern of the first and second years of cadmium exposure, respectively. We marked tested plants with $T_{i-j}(i=1,2$, represents the year after transplanting; $j=7,8,9$, represents the month for sampling).

\subsection{Sampling and Growth Parameter Measurement}

Samples were separated into leaf, shoot, tuber and root, respectively, with the shoot length measured to the nearest millimeter. Samples of leaf, shoot, tuber and root were then dried at $80^{\circ} \mathrm{C}$ for $72 \mathrm{~h}$ to determine the dry weight. The samples were then crushed out and screened out to $1 \mathrm{~mm}$ and the samples of $B$. striate were digested by $\mathrm{HNO}_{3}-\mathrm{HClO}_{4}(2: 1)$ and soil available $\mathrm{Cd}$ was extracted using $0.05 \mathrm{M}$ DTPA (Diethylene triamine pentaacetic acid) extracting solution [26]. The contents of $\mathrm{Cd}, \mathrm{K}, \mathrm{Ca}, \mathrm{Mg}$ and $\mathrm{Zn}$ were determined by inductively coupled plasma mass spectrometry (ICP-MS-2030Series, Shimadezu, Japan). In order to minimize the matrix affect during plant metal analysis, standard reference materials (SRM) and standard solutions were used. The changes in soil $\mathrm{pH}$ were monitored with a pH meter (ISTEK Model 4005-08007, Seoul, South Korea).

\subsection{Data Calculation and Analysis}

The total accumulation of $\mathrm{Cd}$ in B. striata was calculated by the following equation: $\mathrm{Cd}$ accumulation in plant tissues $=(\mathrm{Cd}$ content in plant tissues $) \times($ dry matter of plant tissues $)$.

Data were analyzed using SPSS (Ver. 25, Inc., Chicago, IL, USA) for one-way analysis of variance (ANOVA test), LSD multiple comparative and Pearson correlation analysis. All figures in the current study were drawn using Origin 9.1. 


\section{Result}

\subsection{Soil $\mathrm{pH}$ and Available $\mathrm{Cd}$ Content}

The soil $\mathrm{pH}$ was affected by both the $\mathrm{Cd}$ dose and sampling time. The $\mathrm{pH}$ value in $\mathrm{T}_{2}$ was significantly higher than that in $\mathrm{T}_{1}$ (about 0.63 units on average). The $\mathrm{pH}$ value in $\mathrm{T}_{1}$ increased gradually with time, and tended to be stable in $\mathrm{T}_{2}$. An interesting result was observed only at $54.6 \mathrm{mg} / \mathrm{kg} \mathrm{Cd}$ treatment where soil $\mathrm{pH}$ exhibited a decrease with time in $\mathrm{T}_{2}$. Cd stress caused a significant basification in all Cd-treated soil samples. In $\mathrm{T}_{1}$, soil $\mathrm{pH}$ had an upward trend with increasing $\mathrm{Cd}$ concentration while in $\mathrm{T}_{2}$, soil $\mathrm{pH}$ rose first and then decreased with increasing $\mathrm{Cd}$ concentration; the highest $\mathrm{pH}$ value was observed at $1.00 \mathrm{mg} / \mathrm{kg}$ Cd treatment (Figure 1).

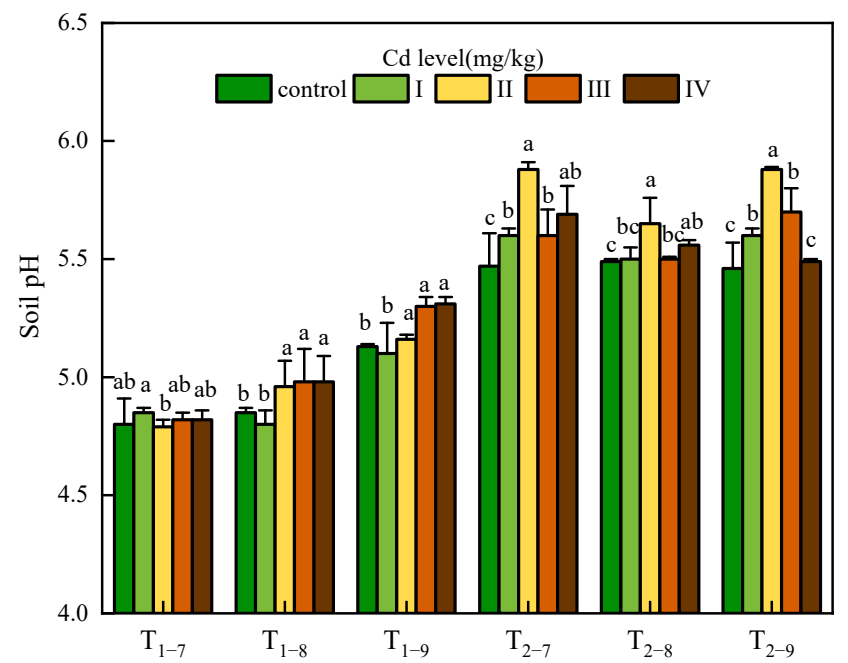

Figure 1. Soil $\mathrm{pH}$ under $\mathrm{Cd}$ treatment control, I, II, III and IV. $\mathrm{T}_{\mathrm{i}-\mathrm{j}}$ means soil sampled at a certain point ( $i=1,2$, represents the year after transplanting; $j=7,8,9$, represents the month for sampling). Error bars indicate standard deviation calculated for three replicates. Significant effects of each treatment on values for soil $\mathrm{pH}$ are denoted by different lowercase letters (one-way analysis of variance (ANOVA), $p<0.05)$.

The available $\mathrm{Cd}$ content increased strictly with the increase of $\mathrm{Cd}$ concentration, and showed an upward trend over time (except $\mathrm{T}_{2-9}$ ). In $\mathrm{T}_{2-9}$, the available $\mathrm{Cd}$ content decreased significantly compared with $\mathrm{T}_{2-8}$ at the same $\mathrm{Cd}$ concentration treatment. Another noteworthy phenomenon is that some measured values were higher than the experimental Cd concentration (especially in 7.39 and $54.6 \mathrm{mg} / \mathrm{kg}$ Cd treatment) (Table 1).

Table 1. Available Cd content of soil under Cd treatment control, I, II, III and IV).

\begin{tabular}{cccccccc}
\hline & Cd Treatment & $\mathbf{T}_{\mathbf{1 - 7}}$ & $\mathbf{T}_{\mathbf{1 - 8}}$ & $\mathbf{T}_{\mathbf{1 - 9}}$ & $\mathbf{T}_{\mathbf{2 - 7}}$ & $\mathbf{T}_{\mathbf{2 - 8}}$ & $\mathbf{T}_{\mathbf{2 - 9}}$ \\
\hline & control & $0.49 \pm 0.02^{\mathrm{c}}$ & $0.48 \pm 0.02^{\mathrm{d}}$ & $0.61 \pm 0.01^{\mathrm{c}}$ & $1.12 \pm 0.01^{\mathrm{c}}$ & $1.15 \pm 0.04^{\mathrm{d}}$ & $0.86^{\mathrm{C}} \pm 0.03^{\mathrm{d}}$ \\
available & I & $0.88 \pm 0.03^{\mathrm{c}}$ & $0.57 \pm 0.03^{\mathrm{d}}$ & $1.21 \pm 0.01^{\mathrm{c}}$ & $1.23 \pm 0.02^{\mathrm{c}}$ & $1.77 \pm 0.43^{\mathrm{c}}$ & $1.44^{\mathrm{c}} \pm 0.05^{\mathrm{d}}$ \\
Cd & II & $1.05 \pm 0.09^{\mathrm{c}}$ & $1.38 \pm 0.07^{\mathrm{c}}$ & $1.86 \pm 0.00^{\mathrm{c}}$ & $1.97 \pm 0.08^{\mathrm{c}}$ & $1.89 \pm 0.32^{\mathrm{c}}$ & $1.71 \pm 0.07^{\mathrm{c}}$ \\
$(\mathrm{mg} / \mathrm{kg})$ & III & $4.59 \pm 0.02^{\mathrm{b}}$ & $7.33 \pm 0.04^{\mathrm{b}}$ & $11.02 \pm 0.53^{\mathrm{b}}$ & $11.92 \pm 2.42^{\mathrm{b}}$ & $14.83 \pm 2.43^{\mathrm{b}}$ & $10.31 \pm 0.35^{\mathrm{b}}$ \\
& IV & $49.44 \pm 0.85^{\mathrm{a}}$ & $54.24 \pm 1.53^{\mathrm{a}}$ & $54.26 \pm 3.53^{\mathrm{a}}$ & $61.42 \pm 5.63^{\mathrm{a}}$ & $68.96 \pm 6.42^{\mathrm{a}}$ & $59.16 \pm 4.53^{\mathrm{a}}$ \\
\hline
\end{tabular}

$T_{i-j}$ means soil sampled at a certain point ( $i=1,2$, represents the year after transplanting; $j=7,8,9$, represents the month for sampling). Values are demonstrated by means $\pm \mathrm{SD}(n=3)$. Significant effects of each treatment on values for available Cd content are denoted by different lowercase letters (one-way ANOVA, $p<0.05$ ).

\subsection{Effect of $C d$ on Plant Growth}

In the short-term $\left(\mathrm{T}_{1}\right)$, cadmium exposure had a significant promotion effect in the biomass of leaves, and the shoots, tubers and roots show no obvious response to cadmium stress. Under long-term cadmium exposure $\left(T_{2}\right)$, the biomass of the leaves and shoots 
showed slightly increase, tubers and roots showed slightly decrease at low $\mathrm{Cd}$ dose $(0.37$ and $1.00 \mathrm{mg} / \mathrm{kg}$ ) compared to controls. At high Cd dose (7.39 and $54.6 \mathrm{mg} / \mathrm{kg}$ ), all tissues showed significant decrease of biomass compared to controls. At the $\mathrm{Cd}$ concentration, the growth of all tissues was almost stagnant in the second year, and the biomass in roots of $T_{2}$ was even lower than $\mathrm{T}_{1}$ at the $\mathrm{Cd}$ concentration of $54.6 \mathrm{mg} / \mathrm{kg}$ (Figure 2).

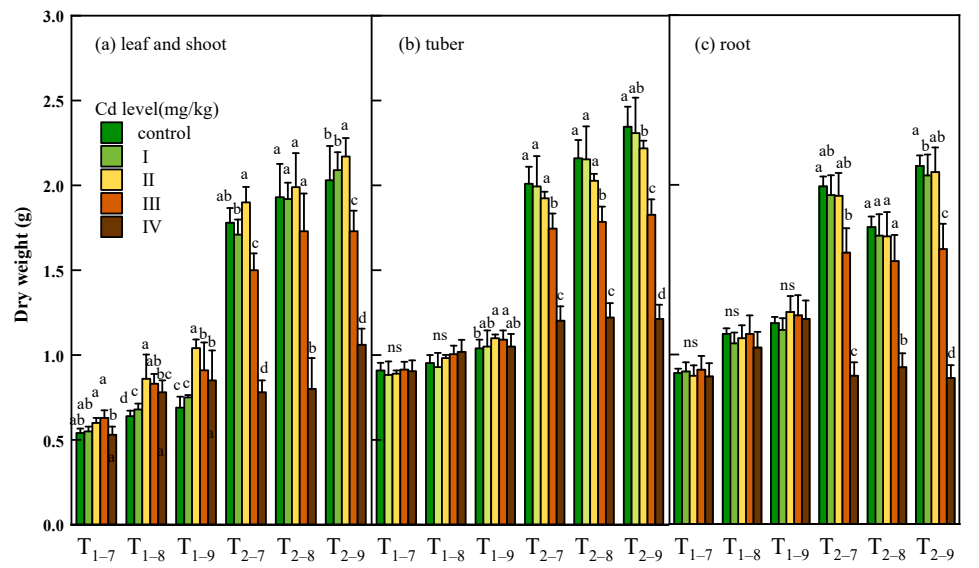

Figure 2. Dry weight of leaf and shoot (a), tuber (b) and root (c) of Bletilla striata (B. striata) plants under Cd treatment control, I, II, III and IV. $\mathrm{T}_{\mathrm{i}-\mathrm{j}}$ means $B$. striata harvested at a certain point $(\mathrm{i}=$ 1,2 , represents the year after transplanting; $j=7,8,9$, represents the month for sampling). Values demonstrate means $\pm \mathrm{SD}(n=3)$. Significant effects of each treatment on values for dry weight are denoted by different lowercase letters (one-way ANOVA, $p<0.05$ ).

\subsection{Cd Content, Accumulation and Distribution}

The $\mathrm{Cd}$ content and accumulation of all tissues of B. striata were observed to increase significantly with increasing $\mathrm{Cd}$ dosage $(p<0.05)$ and exposure time. The maximum $\mathrm{Cd}$ content $(67.02,49.12,881.04 \mathrm{mg} / \mathrm{kg}$ dry weight) and accumulation $(68.75,62.51,772.2 \mu \mathrm{g})$ in leaf and shoot, tuber, root subjected to $54.6 \mathrm{mg} / \mathrm{kg} \mathrm{Cd}$ were recorded. Cadmium accumulates mainly in the root and transfers a small amount to the leaves, shoots and tubers (Figure 3, Table S1). The Cd distribution percentage analysis further suggests that much less $\mathrm{Cd}$ was transferred from the roots to the tubers. Moreover, at 7.39 and $54.6 \mathrm{mg} / \mathrm{kg} \mathrm{Cd}$ treatment, the Cd distribution percent decreased significantly in the tubers compared to the low Cd treatment (Figure 4, Table S1).

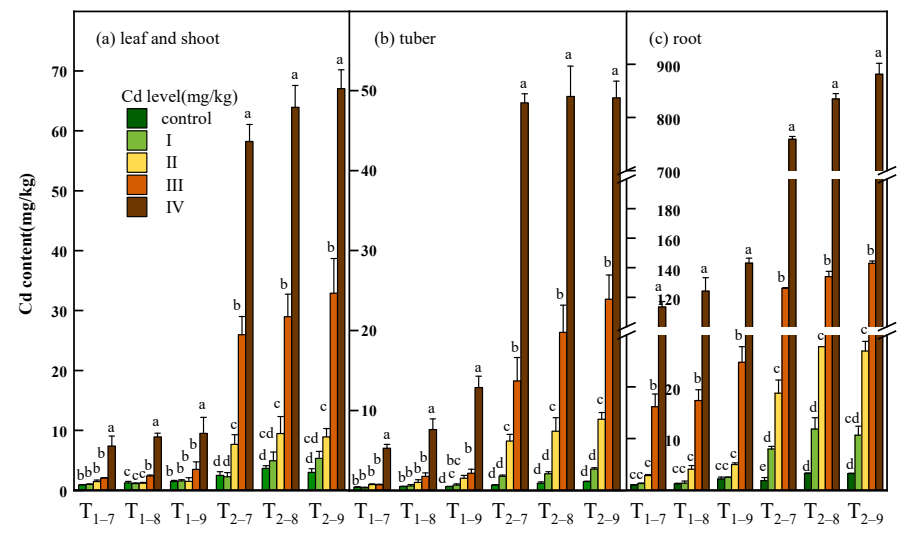

Figure 3. Cd content in leaf and shoot (a), tuber $(\mathbf{b})$ and root (c) of B. striata plants under Cd treatment control, I, II, III and IV. $\mathrm{T}_{\mathrm{i}-\mathrm{j}}$ means $B$. striata harvested at a certain point $(\mathrm{i}=1,2$, represents the year after transplanting; $j=7,8,9$, represents the month for sampling). Error bars indicate standard deviation calculated for three replicates. Significant effects of treatment on values for Cd content are denoted by different lowercase letters (one-way ANOVA, $p<0.05$ ). 


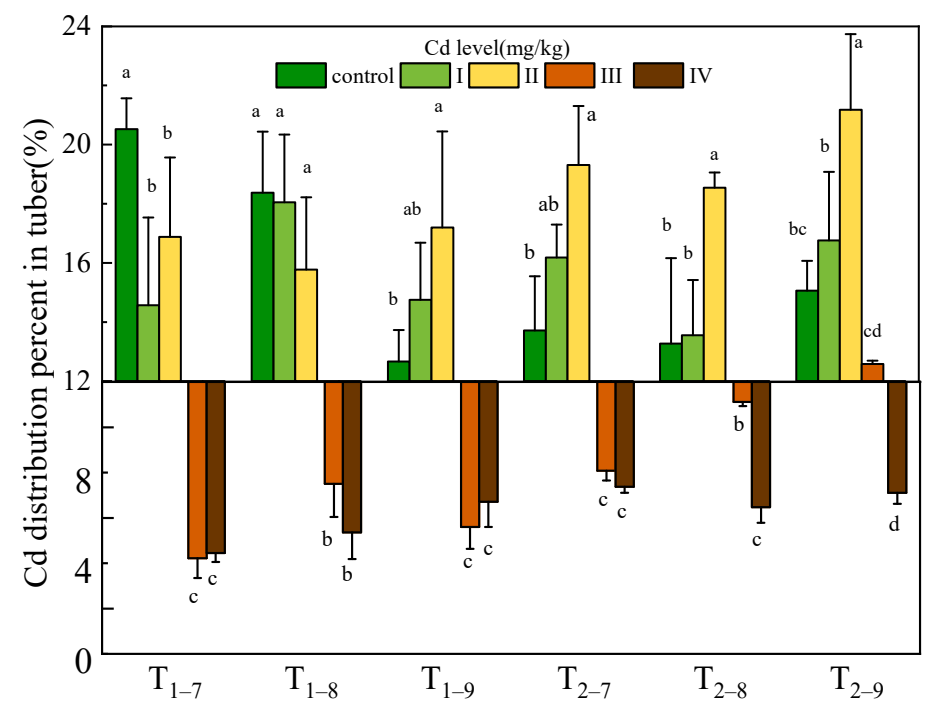

Figure 4. Cd distribution percent in tuber of B. striata plants under Cd treatment control, I, II, III and IV. $\mathrm{T}_{\mathrm{i}-\mathrm{j}}$ means Bletilla striata harvested at a certain point $(\mathrm{i}=1,2$, represents the year after transplanting; $j=7,8,9$, represents the month for sampling). Error bars indicate standard deviation calculated for three replicates. Significant effects of each treatment on values for distribution percent are denoted by different lowercase letters (one-way ANOVA, $p<0.05$ ).

\subsection{Effect of $C d$ Exposure on Nutrient Distribution Pattern}

With the exception of the contents of $\mathrm{Ca}$ and $\mathrm{Mg}$, the $\mathrm{Cd}$ stress significantly affected the $\mathrm{K}$ and $\mathrm{Zn}$ content in treated plants. Specifically, the $\mathrm{K}$ content in the leaves and tubers of $\mathrm{Cd}$-treated plants increased with the increase in $\mathrm{Cd}$ toxicity levels and the maximum value was observed at $54.6 \mathrm{mg} / \mathrm{kg} \mathrm{Cd}$. Under Cd-treated groups, $\mathrm{K}$ content in shoots and roots decreased at $\mathrm{T}_{1}$ and $\mathrm{T}_{2-7}$ compare to control (Table $\mathrm{S} 2$ ).

Magnesium $(\mathrm{Mg})$ remained stable in the leaves in $\mathrm{T}_{1}$, but increased in $\mathrm{T}_{2}$ compared with the controls and was higher than that in $\mathrm{T}_{1}$. Cd treatment had little effect on the content of $\mathrm{Mg}$ in the shoots, but increased significantly at high $\mathrm{Cd}$ concentration in $\mathrm{T}_{2}$. The $\mathrm{Mg}$ content was the highest in the roots compared with other tissues and no significant changes were observed after cadmium treatment (Table S3).

Little change in Ca content was caused by Cd stress, and Ca content in shoots and tubers were functions primarily related to the growth time that showed an increase in the growth season of the same year (Table S4).

The effect of cadmium addition on the $\mathrm{Zn}$ content of B. striata was similar in all tissues, a decrease at low $\mathrm{Cd}$ concentration and an increase at high $\mathrm{Cd}$ concentration were observed, and increased significantly with time in the growing season of the same year (Table S5). In the $T_{1}, Z n$ content increased from $T_{1-7}$ to $T_{1-9}$ regardless of $C d$ concentration and the part of the plant. One interesting observation, however, is that $\mathrm{Zn}$ content was at a significantly lower level at $\mathrm{T}_{2-7}$ compared to $\mathrm{T}_{1-9}$ and gradually increased.

\subsection{Accumulation of $\mathrm{K}, \mathrm{Mg}, \mathrm{Ca}$ and $\mathrm{Zn}$ in Tubers of Plants}

Table $S 6$ shows that the tubers accumulate the highest $\mathrm{Zn}$ at a $\mathrm{Cd}$ dose of $1.00 \mathrm{mg} / \mathrm{kg}$ (II) in $\mathrm{T}_{1}$ and at a Cd dose of $0.37 \mathrm{mg} / \mathrm{kg}$ (I) in $\mathrm{T}_{2}$, except $\mathrm{T}_{2-7}$. The high Cd dose $(54.6 \mathrm{mg} / \mathrm{kg}$ ) significantly reduced $\mathrm{Zn}$ accumulation compared to the control only in the second year $\left(\mathrm{T}_{2}\right)$. The accumulation of $\mathrm{K}, \mathrm{Mg}$ and $\mathrm{Ca}$ in the tubers of the tested-plants had no significant difference in $\mathrm{T}_{1}$ whereas they were significantly lower than those of the controls in $\mathrm{T}_{2}$ and decreased with increased $\mathrm{Cd}$ dosage.

\subsection{Relationship between $\mathrm{Cd}$ Accumulation and Nutrient Allocation Pattern}

The Pearson correlation analysis provides further evidence that there was a significant relationship between the accumulation and transport of nutrients, and $\mathrm{Cd}$ accumulation 
and translocation (Table 2). In $\mathrm{T}_{1}, \mathrm{Cd}$ accumulation in both the tuber and root were positively correlated with the translocation factor of $\mathrm{K}$ and $\mathrm{Zn}$ and there was no significant relationship with nutrient accumulation, except in promoting $\mathrm{K}$ enrichment. In $\mathrm{T}_{2}, \mathrm{Cd}$ accumulation was positively correlated with the translocation factors of $\mathrm{K}$ and $\mathrm{Zn}$, and negatively correlated with nutrient accumulation. The translocation factors of $\mathrm{K}$ and $\mathrm{Zn}$ were negatively correlated with the translocation factor of $\mathrm{Cd}$.

Table 2. The relationships between $\mathrm{Cd}$ accumulation and translocation, and nutrient accumulation and allocation.

\begin{tabular}{ccccccccccccccccc}
\hline Pearson & $\mathbf{K}_{\mathbf{1}}$ & $\mathbf{M}_{\mathbf{1}}$ & $\mathbf{C}_{\mathbf{1}}$ & $\mathbf{Z}_{\mathbf{1}}$ & $\mathbf{T F}_{\mathbf{K} 1}$ & $\mathbf{T F}_{\mathbf{M} 1}$ & $\mathbf{T F}_{\mathbf{C} 1}$ & $\mathbf{T F}_{\mathbf{Z 1}}$ & $\mathbf{K}_{\mathbf{2}}$ & $\mathbf{M}_{\mathbf{2}}$ & $\mathbf{C}_{\mathbf{2}}$ & $\mathbf{Z}_{\mathbf{2}}$ & $\mathbf{T F}_{\mathbf{K} 2}$ & $\mathbf{T F}_{\mathbf{M} 2}$ & $\mathbf{T F}_{\mathbf{C 2}}$ & $\mathbf{T F}_{\mathbf{Z} 2}$ \\
\hline AccumuT1 & $0.404^{* *}$ & -0.024 & 0.009 & 0.136 & $0.572^{* *}$ & 0.016 & -0.125 & $0.435^{* *}$ & -0.199 & $-0.439^{* *}$ & $-0.583^{* *}$ & -0.111 & $0.447^{* *}$ & -0.112 & $-0.317^{*}$ & 0.109 \\
AccumuR1 & $0.303^{*}$ & -0.062 & -0.058 & 0.067 & $0.566^{* *}$ & 0.015 & -0.114 & $0.405^{* *}$ & -0.293 & $-0.543^{* *}$ & $-0.686^{* *}$ & -0.198 & $0.635^{* *}$ & 0.015 & $-0.371^{*}$ & 0.186 \\
$\mathrm{TF}_{\mathrm{Cd} 1}$ & 0.132 & 0.046 & 0.022 & 0.024 & -0.199 & 0.041 & -0.007 & $-0.437^{* *}$ & 0.265 & $0.485^{* *}$ & $0.616^{* *}$ & 0.211 & $-0.589^{* *}$ & -0.144 & 0.261 & $-0.569^{* *}$ \\
AccumuT2 & 0.095 & 0.063 & 0.02 & 0.106 & $0.437^{* *}$ & 0.113 & 0.008 & $0.545^{* *}$ & -0.153 & $-0.517^{* *}$ & $-0.705^{* *}$ & -0.142 & $0.689^{* *}$ & 0.049 & $-0.365^{*}$ & $0.298^{*}$ \\
AccumuR2 & 0.145 & -0.099 & -0.082 & -0.047 & $0.410^{* *}$ & -0.044 & -0.122 & $0.409^{* *}$ & $-0.357^{*}$ & $-0.590^{* *}$ & $-0.772^{* *}$ & -0.27 & $0.760^{* *}$ & 0.125 & $-0.419^{* *}$ & $0.323^{*}$ \\
$\mathrm{TF}_{\mathrm{Cd} 2}$ & 0.045 & 0.212 & 0.066 & 0.14 & -0.284 & 0.178 & 0.057 & $-0.296^{*}$ & 0.286 & $0.373^{*}$ & $0.738^{* *}$ & 0.158 & $-0.665^{* *}$ & -0.249 & $0.571^{* *}$ & $-0.499^{* *}$ \\
\hline
\end{tabular}

Note: * means $p<0.05,{ }^{* *}$ means $p<0.01$. K means potassium, M means magnesium, $\mathrm{C}$ means calcium, $\mathrm{Z}$ means zinc, $\mathrm{T}$ means tuber, $\mathrm{R}$ means root, TF means translocation factor, " 1 " means first year of Cd exposure, " 2 " means the next year of Cd exposure. Accumu means accumulation in tuber or root.

The translocation factor ( $\mathrm{TF}, \%$ ) from root to tuber for $\mathrm{Cd}, \mathrm{K}, \mathrm{Mg}$, $\mathrm{Ca}, \mathrm{Zn}$ was calculated from Equation (1)

$$
\mathrm{TF}=(100) \times(\text { content in tuber }) /(\text { content in root })
$$

\section{Discussion}

Cd stress induces plants to modulate (either basification or acidification) surrounding medium $\mathrm{pH}$. Here, we observed that medium responded to $\mathrm{Cd}$ stress by causing a significant basification, not acidification as was originally hypothesized. Nocito et al. [27] showed that $\mathrm{Cd}$ treatment of root cells resulted in a significant reduction in both cytosolic and vacuolar $\mathrm{pH}$. It seems likely that roots either take up $\mathrm{H}+$ ions or release $\mathrm{OH}-$ and thereby cause medium basification. Another possibility is that metal stress stimulated the co-release of organic anions along with nutrient cations [28], thereby causing rhizosphere and medium basification. However, the medium acidification of $\mathrm{T}_{2}$ observed at $54.6 \mathrm{mg} / \mathrm{kg}$ $\mathrm{Cd}$ concentration may be due to the loss of cations from the soil caused by excessive accumulation of $\mathrm{Cd}$. We observed the available $\mathrm{Cd}$ content enriched near the rhizosphere due to plant absorption, resulting in higher available $\mathrm{Cd}$ concentration compared to background treatment concentration, in some rhizosphere soil samples. In $\mathrm{T}_{2-9}$, the available $\mathrm{Cd}$ content was lower than that in $\mathrm{T}_{2-8}$ under all $\mathrm{Cd}$-treated groups. The root absorption of divalent cations and the competitive transport of Cd could reveal this phenomenon [29], which is related to the mechanism of plant stress resistance under excess $\mathrm{Cd}$ accumulation.

According to previous studies, the uptake, accumulation and distribution of $\mathrm{Cd}$ in different plant organs are varied [30], and most of the $\mathrm{Cd}$ is accumulated in the roots, with very little $\mathrm{Cd}$ transported to the shoots. Similar results were obtained in this experiment. Our findings demonstrate that roots accumulate $\mathrm{Cd}$ to much higher levels than the other plant tissues at a comparable $\mathrm{Cd}$ exposure. The roots of $B$. striata have the highest capacity of $\mathrm{Cd}$ uptaken and the proportion of accumulated amount increased with the increased $\mathrm{Cd}$ level and decreased slightly with exposure time due to $\mathrm{Cd}$ transport to the shoots and leaves. Moreover, we found that the allocation percent of cadmium accumulation in tubers was lower at medium to high soil $\mathrm{Cd}$ exposure compared to low $\mathrm{Cd}$ exposure.

Short-term exposure to certain concentrations of cadmium significantly increased the growth of leaves, shoots and roots. The different promotion $\mathrm{Cd}$ concentrations and accumulations revealed a higher $\mathrm{Cd}$ tolerance in the roots in relation to the leaves and shoots. Tuber growth of B. striata was not impacted. The promotion effect of low soil $\mathrm{Cd}$ concentration on the growth of Bletilla striata may involve an adaptive compensation process, such as cell proliferation and division as a reaction to oxidative stress [31]. With much higher $\mathrm{Cd}$ content and accumulation in roots than the other tissues, $\mathrm{Cd}$ accumulation 
in the roots seem to be the major cause for lower dry weight in $\mathrm{T}_{2}$ compared to $\mathrm{T}_{1}$ [32]. Highconcentration cadmium in the roots may interfere with the oxidation-reduction balance and the improvement of active oxygen level, resulting in poor root growth. The biomass of the other tissues was also lower than control levels due to cadmium accumulation under long-term high cadmium $(\geq 7.39 \mathrm{mg} / \mathrm{kg}$ ) exposure.

Plants have evolved a method of adapting to $\mathrm{Cd}$ and better grow by allocating nutrients in the organs [29]. The results showed that K firstly was transported from the roots to the aboveground part and from shoots to leaves, then the $\mathrm{K}$ in the shoots rises to a higher level than the controls at low $\mathrm{Cd}$ concentrations $(0.37,1.00 \mathrm{mg} / \mathrm{kg})$ and comparable levels at high $\mathrm{Cd}$ concentrations $(7.39,54.6 \mathrm{mg} / \mathrm{kg})$ in the second year of $\mathrm{Cd}$ exposure, respectively. Considering the growth conditions, the improvement of the $\mathrm{K}$ content in leaves and shoots may be due to enhanced uptake and/or translocation of mineral nutrients at low $\mathrm{Cd}$ concentrations and the "concentration effect" at high concentration, indicating the increase of the $\mathrm{K}$ content and absorption in leaves of $B$. striata is an important detoxification mechanism. The $\mathrm{K}$ content in tubers increased significantly only in $\mathrm{T}_{2}$ at high concentration of cadmium treatment, which can be also interpreted as the "concentration effect" caused by excessive accumulation of cadmium. Signs of potassium deficiency are a reduction in growth rates and resistance and premature senescence. The roots transport large amounts of $\mathrm{K}$ to the other tissues, resulting in decreases in both the biomass and $\mathrm{K}$ content.

$\mathrm{Ca}$ and $\mathrm{Mg}$ are important elements for $\mathrm{B}$. striata growth, which are mainly affected by growth time rather than cadmium concentration. The $\mathrm{Ca}$ and $\mathrm{Mg}$ content in the shoots and tubers increased with time during the growing season of the same year for stretching and enlarging. The balance state between accelerated absorption for growth and competition of transport factors may explain a few of the changes of $\mathrm{Ca}$ and $\mathrm{Mg}$ content in all treatment groups. The $\mathrm{Zn}$ content is a function of time and cadmium concentration. Cadmium exposure increases the $\mathrm{Zn}$ content in all tissues (except roots) and the maximum values were observed at $\mathrm{Cd}$ concentrations of 0.37 and $1.00 \mathrm{mg} / \mathrm{kg}$. The decrease of zinc content in roots was consistent with the findings of Wang et al. [33] The reduction in Zn uptake was likely due to the high $\mathrm{Cd}$ content and accumulation in the cytosol of the root cells, which impedes ZIP (zinc-regulated transporters, iron-regulated transporter-like protein) transporters in root uptaking and translocating. It is speculated that the uptake and translocation of $\mathrm{K}$ and $\mathrm{Zn}$ in each tissue of $B$. striata may affect the biomass and homeostasis regulation such as photosynthesis, protein synthesis, enzyme activation and the like because both $\mathrm{K}$ and $\mathrm{Zn}$ are important coenzyme factors.

The Cd accumulation in tubers with the $\mathrm{Cd}$ concentration increase are associated with a decrease of nutriment accumulation. The Pearson correlation analysis showed that $\mathrm{Cd}$ accumulation in both the tuber and root were positively correlated with accumulation of $\mathrm{K}$ and $\mathrm{Zn}$ in $\mathrm{T}_{1}$ and negatively correlated with $\mathrm{K}, \mathrm{Ca}, \mathrm{Mg}$ and $\mathrm{Zn}$ in $\mathrm{T}_{2}$. Zinc was the most significant antagonistic factor to $\mathrm{Cd}$. The antagonistic interaction of the translocation factors of $\mathrm{Zn}$ and $\mathrm{Cd}$ is predictable, because $\mathrm{Cd}$ can enter the plants cells by competing for transporter and channel protein [34,35].Thus, $\mathrm{Cd}$ uptake is related to cation absorption, and $\mathrm{Cd}$ accumulation will be reduced when abundant divalent cations are present. The tubers demonstrated the highest $\mathrm{Zn}$ accumulation at a $\mathrm{Cd}$ dose of $1.00 \mathrm{mg} / \mathrm{kg}$ (II) in the first year $\left(\mathrm{T}_{1}\right)$ and at a $\mathrm{Cd}$ dose of $0.37 \mathrm{mg} / \mathrm{kg}(\mathrm{I})$ in the second year $\left(\mathrm{T}_{2}\right)$, except $\mathrm{T}_{2-7}$. The high $\mathrm{Cd}$ dose $(54.6 \mathrm{mg} / \mathrm{kg}$ ) significantly reduced $\mathrm{Zn}$ accumulation compared to the control only in the second year $\left(\mathrm{T}_{2}\right)$. This is because when $\mathrm{Cd}$ is accumulated in an appropriate amount, B. striata will promote the transport of nutrient elements to resist Cd stress. However, in the case of excessive $\mathrm{Cd}$ accumulation, the ability of zinc to compete for transport factors with $\mathrm{Cd}$ is greatly weakened, which exceeds the regulatory range of plants, leading to the decrease of zinc content. An another interesting observation is that $\mathrm{Zn}$ content was at a significantly lower level at $\mathrm{T}_{2-7}$ compared to $\mathrm{T}_{1-9}$ and gradually increased. During the seed-bearing period from July to September, B. striata had high physiological activity, which promoted the absorption and transport of zinc for growth and development [36]. 
After September, B. striata enters a long dormant period and anthesis with Zn consumption, resulting in lower levels in $\mathrm{T}_{2-7}$ compared to $\mathrm{T}_{1-9}$.

$\mathrm{K}$ not only improves the synthesis of glutathione and protein, but also activates synthase, redox enzyme and transferase [37-39]. Tan et al. [29] found that nutrient allocation of $\mathrm{K}$ might affect the $\mathrm{Cd}$ accumulation which suggests a common mechanism whereby plants compensate for interrupted mineral nutrient metabolism by increasing the nutrient supply to their tissues. Zinc is also an important component in the biosynthesis of some antioxidant enzymes which will increase by oxidative stress caused by $\mathrm{Cd}$. Numerous researchers have shown that $\mathrm{Zn}$ is capable of reducing the $\mathrm{Cd}$ uptake due to the similar properties of $\mathrm{Zn}$ and $\mathrm{Cd}$ [40-43]. In addition, $\mathrm{Zn}$ can enhance growth by decreasing oxidative stress, improving photosynthesis [44], and enhancing photosynthetic performance [41]. Therefore, the increase of nutrient allocation in tubers can prevent further accumulation of $\mathrm{Cd}$ in plants and reduce the toxicity induced by $\mathrm{Cd}$. Due to the competition of the transporters, the accumulation of cadmium in the roots and tubers of $B$. striata has a negative effect on the absorption of nutrients, but promotes the translocation factor of nutrients from the roots to tubers to help in the synthesis of antioxidant enzymes and prevent further accumulation of cadmium.

\section{Conclusions}

Here, we present the first report on the relationship between cadmium stress and the nutrient distribution pattern of B. striata. We characterized $\mathrm{Cd}$ accumulation and the temporal dynamics of the nutrients allocation pattern in $B$. striata. The results revealed that $\mathrm{Cd}$ mainly accumulated in the roots and much less in the tubers. The yield of Bletilla striata will not be significantly affected when cultivated in soil with a concentration of cadmium $\leq 1 \mathrm{mg} / \mathrm{kg}$. Through dynamic changes in the nutrient element content, we confirmed that $B$. striata transported $\mathrm{K}$ to the aboveground part and tuber under $\mathrm{Cd}$ stress. The absorption of $\mathrm{Zn}$ increased significantly with growing time and increased first and then decreased with the increase of cadmium treatment. There was no significant difference in the Ca content between the treatment groups and associated with the growth time in tubers and shoots. The $\mathrm{Mg}$ content remained relatively stable in all components except that an increase was observed in shoots under a high Cd level. B. striata can schedule the nutrients allocation pattern in plant organs to adjust to the enrichment of $\mathrm{Cd}$. Considering the importance of the tuber as a medicinal part of Bletilla striata and the "concentration effect" due to changes in biomass, we further demonstrated a positive correlation between the $\mathrm{Cd}$ accumulation and the translocation factors of $\mathrm{K}$ and $\mathrm{Zn}$ in tubers through Pearson analysis. Translocation of the nutrient elements have an antagonistic effect on the $\mathrm{Cd}$ translocation factor, helping to alleviate the toxic effect of $\mathrm{Cd}$ in B. striata. Based on the above findings, we concluded that nutrients management can prevent further accumulation of $\mathrm{Cd}$ by promoting the translocation factors of the nutrients and inhibiting the uptake of $\mathrm{Cd}$ in B. striata. In addition, we recommended that changes in the mineral nutrient pattern should be included when potential Cd toxicity in plants is assessed and more extensive test periods need to be established.

Supplementary Materials: The following are available online at https:/ / www.mdpi.com/article/10 .3390/agriculture11070594/s1, Table S1: Cd accumulation of in leaf and shoot, tuber, root of B. striata under Cd treatment control, I, II, III and IV. Table S2: K content in leaf, shoot, tuber, root of B. striata under Cd treatment control, I, II, III and IV. Table S3: Mg content in leaf, shoot, tuber, root of B. striata under Cd treatment control, I, II, III and IV. Table S4: Ca content in leaf, shoot, tuber, root of B. striata under Cd treatment control, I, II, III and IV. Table S5: Zn content in leaf, shoot, tuber, root of B. striata under Cd treatment control, I, II, III and IV. Table S6: Accumulation of K, Mg, Ca and Zn in tuber of B. striata under Cd treatment control, I, II, III and IV.

Author Contributions: Conceptualization, H.S.; methodology, J.Y. and H.S.; software, X.W.; formal analysis, J.Q.; investigation, J.Y. and X.W.; writing—original draft preparation, J.Y.; writing—review and editing, H.S.; project administration, H.S.; funding acquisition, H.S. and W.C. All authors have read and agreed to the published version of the manuscript. 
Funding: This research was funded by the National Key Research and Development Program of China (No.2017YFC1700705).

Conflicts of Interest: The authors declare that they have no known competing financial interest or personal relationships that could appear to influence the work reported in this paper.

\section{References}

1. He, X.; Wang, X.; Fang, J.; Zhao, Z.; Huang, L.; Guo, H.; Zheng, X. Bletilla striata: Medicinal uses, phytochemistry and pharmacological activities. J. Ethnopharmacol. 2017, 195, 20-38. [CrossRef]

2. Wang, C.; Tian, M. Seventeen novel microsatellite markers for a valuable medicinal plant Bletilla striata and cross-amplification in B. ochracea. Conserv. Genet. Resour. 2015, 7, 715-716. [CrossRef]

3. Li, R.; Wang, Z.Z. Research survey and countermeasure on resources utilization in stem tuber of Bletilla striata. Chin. Tradit. Herb. Drugs 2006, 37, 1751-1755. [CrossRef]

4. Sanità di Toppi, L.; Gabbrielli, R. Response to cadmium in higher plants. Environ. Exp. Bot. 1999, 41, 105-130. [CrossRef]

5. Shah, K.; Dubey, R.S. Cadmium elevates level of protein, amino acids and alters activity of proteolytic enzymes in germinating rice seeds. Acta Physiol. Plant. 1998, 20, 189-196. [CrossRef]

6. Laporte, M.-A.; Sterckeman, T.; Dauguet, S.; Denaix, L.; Nguyen, C. Variability in cadmium and zinc shoot concentration in 14 cultivars of sunflower (Helianthus annuus L.) as related to metal uptake and partitioning. Environ. Exp. Bot. 2015, 109, 45-53. [CrossRef]

7. Yang, J.; Guo, H.; Ma, Y.; Wang, L.; Wei, D.; Hua, L. Genotypic variations in the accumulation of Cd exhibited by different vegetables. J. Environ. Sci. 2010, 22, 1246-1252. [CrossRef]

8. Tanwir, K.; Akram, M.S.; Masood, S.; Chaudhary, H.J.; Lindberg, S.; Javed, M.T. Cadmium-induced rhizospheric pH dynamics modulated nutrient acquisition and physiological attributes of maize (Zea mays L.). Environ. Sci. Pollut. Res. 2015, 22, 9193-9203. [CrossRef]

9. Chen, X.D.; Shan, C.J. Cerium nitrate improves salt tolerance of wheat seedlings by regulating the antioxidant capacity of chloroplasts. Biol. Plant. 2019, 63, 323-327. [CrossRef]

10. Tessier, J.T.; McNaughton, S.J.; Raynal, D.J. Influence of nutrient availability and tree wildling density on nutrient uptake by Oxalis acetosella and Acer saccharum. Environ. Exp. Bot. 2001, 45, 11-20. [CrossRef]

11. Jordan-Meille, L.; Pellerin, S. Shoot and root growth of hydroponic maize (Zea mays L.) as influenced by K deficiency. Plant Soil 2008, 304, 157-168. [CrossRef]

12. Ouzounidou, G. Copper-induced changes on growth, metal content and photosynthetic function of Alyssum montanum L. plants. Environ. Exp. Bot. 1994, 34, 165-172. [CrossRef]

13. Greger, M.; Lindberg, S. Effects of $\mathrm{Cd}^{2+}$ and EDTA on young sugar beets (Beta vulgaris). I. Cd ${ }^{2+}$ uptake and sugar accumulation. Physiol. Plant. 1986, 66, 69-74. [CrossRef]

14. Shukla, U.C.; Murthy, R.C.; Kakkar, P. Combined effect of ultraviolet-B radiation and cadmium contamination on nutrient uptake and photosynthetic pigments in Brassica campestris L. seedlings. Environ. Toxicol. 2008, 23, 712-719. [CrossRef]

15. Li, X.; Zhou, Q.; Sun, X.; Ren, W. Effects of cadmium on uptake and translocation of nutrient elements in different welsh onion (Allium fistulosum L.) cultivars. Food Chem. 2016, 194, 101-110. [CrossRef]

16. Liu, J.G.; Liang, J.S.; Li, K.Q.; Zhang, Z.J.; Yu, B.Y.; Lu, X.L.; Yang, J.C.; Zhu, Q.S. Correlations between cadmium and mineral nutrients in absorption and accumulation in various genotypes of rice under cadmium stress. Chemosphere 2003, 52, 1467-1473. [CrossRef]

17. Monteiro, M.S.; Santos, C.; Soares, A.M.V.M.; Mann, R.M. Assessment of biomarkers of cadmium stress in lettuce. Ecotoxicol. Environ. Saf. 2009, 72, 811-818. [CrossRef]

18. Zorrig, W.; Rouached, A.D.; Shahzad, Z.; Abdelly, C.; Davidian, J.C.; Berthomieu, P. Identification of three relationships linking cadmium accumulation to cadmium tolerance and zinc and citrate accumulation in lettuce. J. Plant Physiol. 2010, 167, 1239-1247. [CrossRef]

19. Xu, J.; Wang, W.; Yin, H.; Liu, X.; Sun, H.; Mi, Q. Exogenous nitric oxide improves antioxidative capacity and reduces auxin degradation in roots of Medicago truncatula seedlings under cadmium stress. Plant Soil 2010, 326, 321-330. [CrossRef]

20. Sarwar, N.; Saifullah Malhi, S.S.; Zia, M.H.; Naeem, A.; Bibi, S.; Farid, G. Role of mineral nutrition in minimizing cadmium accumulation by plants. J. Sci. Food Agric. 2010, 90, 925-937. [CrossRef]

21. Kurtyka, R.; Malkowski, E.; Kita, A.; Karcz, W. Effect of calcium and cadmium on growth and accumulation of cadmium, calcium, potassium and sodium in maize seedlings. Pol. J. Environ. Stud. 2008, 17, 51-56. Available online: https://www.researchgate.net/ publication/259852721 (accessed on 12 February 2021).

22. Drazic, G.; Mihailovic, N. Modification of cadmium toxicity in soybean seedlings by salicylic acid. Plant Sci. 2005, 168, 511-517. [CrossRef]

23. Trejo-Téllez, L.I.; Gómez-Merino, F.; Rivera-Olivares, L.; Tejeda-Sartorius, O. Cadmium-induced changes in leaf nutrient concentrations in sugarcane. J. Food Agric. Environ. 2014, 12, 879-885. Available online: https://www.mendeley.com/catalogue/ c83e97c3-0fa5-32ad-966e-79a2e3dad58c/\#cited\%20by-title (accessed on 8 February 2021).

24. Yang, D.; Guo, Z.; Green, I.D.; Xie, D. Effect of cadmium accumulation on mineral nutrient levels in vegetable crops: Potential implications for human health. Environ. Sci. Pollut. Res. 2016, 23, 19744-19753. [CrossRef] [PubMed] 
25. Gonçalves, J.F.; Antes, F.G.; Maldaner, J.; Pereira, L.B.; Tabaldi, L.A.; Rauber, R.; Rossato, L.V.; Bisognin, D.A.; Dressler, V.L.; de Moraes Flores, É.M.; et al. Cadmium and mineral nutrient accumulation in potato plantlets grown under cadmium stress in two different experimental culture conditions. Plant Physiol. Biochem. 2009, 47, 814-821. [CrossRef] [PubMed]

26. Lindsay, W.L.; Norvell, W.A. Development of a DTPA test for zinc, iron, manganese and copper. Soil Sci. Soc. Am. J. 1978, 42, 421-428. [CrossRef]

27. Nocito, F.F.; Espen, L.; Crema, B.; Cocucci, M.; Sacchi, G.A. Cadmium induces acidosis in maize root cells. New Phytol. 2008, 179, 700-711. [CrossRef]

28. Qin, R.; Hirano, Y.; Brunner, I. Exudation of organic acid anions from poplar roots after exposure to $\mathrm{Al}, \mathrm{Cu}$ and $\mathrm{Zn}$. Tree Physiol. 2007, 27, 313-320. [CrossRef]

29. Tan, S.; Liu, Z.; Zeng, Q.; Zhu, M.; Wang, A.; Chen, B. Nutrient allocation might affect the cadmium accumulation of Bermuda grass (Cynodon dactylon). Chemosphere 2020, 252, 126512. [CrossRef]

30. Grant, C.A.; Buckley, W.T.; Bailey, L.D.; Selles, F. Cadmium accumulation in crops. Can. J. Plant Sci. 1998, 78, 1-17. [CrossRef]

31. Lin, R.; Wang, X.; Luo, Y.; Du, W.; Guo, H.; Yin, D. Effects of soil cadmium on growth, oxidative stress and antioxidant system in wheat seedlings (Triticum aestivum L.). Chemosphere 2007, 69, 89-98. [CrossRef] [PubMed]

32. Chen, Y.X.; He, Y.F.; Luo, Y.M.; Yu, Y.L.; Lin, Q.; Wong, M.H. Physiological mechanism of plant roots exposed to cadmium. Chemosphere 2003, 50, 789-793. [CrossRef]

33. Wang, M.; Zou, J.; Duan, X.; Jiang, W.; Liu, D. Cadmium accumulation and its effects on metal uptake in maize (Zea mays L.). Bioresour. Technol. 2007, 98, 82-88. [CrossRef]

34. Ghasemi, R.; Share, H.; Sharifi, R.; Boyd, R.S.; Rajakaruna, N. Inducing Ni sensitivity in the Ni hyperaccumulator plant Alyssum inflatum Nyárády (Brassicaceae) by transforming with CAX1, a vacuolar membrane calcium transporter. Ecol. Res. 2018, 33, 737-747. [CrossRef]

35. Takahashi, R.; Ishimaru, Y.; Shimo, H.; Ogo, Y.; Senoura, T.; Nishizawa, N.K.; Nakanishi, H. The OsHMA2 transporter is involved in root-to-shoot translocation of $\mathrm{Zn}$ and Cd in rice. Plant Cell Environ. 2012, 35, 1948-1957. [CrossRef]

36. Shi, J. Plant Resources and Utilization of Bletilla striata. Master's Thesis, University of Hainan, Haikou, China, $2010 ;$ pp. 2-36.

37. Huang, Y.; Zhu, Z.; Wu, X.; Liu, Z.; Zou, J.; Chen, Y.; Su, N.; Cui, J. Lower cadmium accumulation and higher antioxidative capacity in edible parts of Brassica campestris L. seedlings applied with glutathione under cadmium toxicity. Environ. Sci. Pollut. Res. 2019, 26, 13235-13245. [CrossRef]

38. Pan, F.; Meng, Q.; Wang, Q.; Luo, S.; Chen, B.; Khan, K.Y.; Yang, X.; Feng, Y. Endophytic bacterium Sphingomonas SaMR12 promotes cadmium accumulation by increasing glutathione biosynthesis in Sedum alfredii Hance. Chemosphere 2016, 154, 358-366. [CrossRef]

39. Wu, Z.; Zhao, X.; Sun, X.; Tan, Q.; Tang, Y.; Nie, Z.; Qu, C.; Chen, Z.; Hu, C. Antioxidant enzyme systems and the ascorbateglutathione cycle as contributing factors to cadmium accumulation and tolerance in two oilseed rape cultivars (Brassica napus L.) under moderate cadmium stress. Chemosphere 2015, 138, 526-536. [CrossRef]

40. Khan, Z.S.; Rizwan, M.; Hafeez, M.; Ali, S.; Javed, M.R.; Adrees, M. The accumulation of cadmium in wheat (Triticum aestivum) as influenced by zinc oxide nanoparticles and soil moisture conditions. Environ. Sci. Pollut. Res. 2019, 26, 19859-19870. [CrossRef]

41. Rizwan, M.; Ali, S.; Hussain, A.; Ali, Q.; Shakoor, M.B.; Zia-ur-Rehman, M.; Farid, M.; Asma, M. Effect of zinc-lysine on growth, yield and cadmium uptake in wheat (Triticum aestivum L.) and health risk assessment. Chemosphere 2017, 187, 35-42. [CrossRef]

42. Wu, C.; Dun, Y.; Zhang, Z.; Li, M.; Wu, G. Foliar application of selenium and zinc to alleviate wheat (Triticum aestivum L.) cadmium toxicity and uptake from cadmium-contaminated soil. Ecotoxicol. Environ. Saf. 2020, 190, 110091. [CrossRef] [PubMed]

43. Zou, R.; Wang, L.; Li, Y.C.; Tong, Z.; Huo, W.; Chi, K.; Fan, H. Cadmium absorption and translocation of amaranth (Amaranthus mangostanus L.) affected by iron deficiency. Environ. Pollut. 2020, 256, 113410. [CrossRef] [PubMed]

44. Liu, W.; Shang, S.; Feng, X.; Zhang, G.; Wu, F. Modulation of exogenous selenium in cadmium-induced changes in antioxidative metabolism, cadmium uptake, and photosynthetic performance in the 2 tobacco genotypes differing in cadmium tolerance. Environ. Toxicol. Chem. 2015, 34, 92-99. [CrossRef] 